\title{
Influence of the geometry, relative position and length of sewer plate heat exchangers on their effectiveness
}

\author{
Alexandr Pushnov \\ Moscow State University \\ of Engineering Ecology, \\ Ul. Staraya Basmannaya, 21 / 4, \\ 105066 Moscow, Russia \\ E-mail:pushnovas@gmail.com
}

\begin{abstract}
The effect of various dimensions of the shape, relative position and length of channels of plate heat exchangers on the effectiveness of the processes of hydrodynamics and heat transfer are analyzed. Based on the general theory of representations of the boundary layer, it is shown that the length of the entrance section of the hydrodynamic stabilization of flow while creating new and more efficient designs of plate heat exchangers should be accounted for. On the basis of the proposed hypothesis about the qualitative hydrodynamic analogy between the flow streams in plate and mixing heat exchangers, the effect of the relative position of the neighboring channels of plates on the hydrodynamics and the efficiency of heat transfer in a plate heat exchanger is shown.
\end{abstract}

Key words: plate heat exchangers, heat exchangers, mixing, geometry of channels, the input section of hydrodynamic stabilization of flow, the efficiency of heat transfer, aerodynamics, surface area, angle of attack

\section{INTRODUCTION}

The basic idea of plate heat exchangers is that one medium (liquid or gas) warms the other, and not the heat exchanger. The process of heat transfer is carried out by transferring heat from one stream of liquid or gas to another without mixing these mediums. In plate heat exchangers, virtually all the material forms a highly efficient plate heat exchange surface. A fragment of the Sondex (Denmark) plate group is shown in Fig. 1. In the case when two adjacent heat transfer plate mirrors are turned to each other at $180^{\circ}$, the corrugations of the adjacent plates intersect, forming channels with a low, high or medium angles of intersection of pairs of adjacent plates. A large angle of the relief plates causes a high resistance and a higher efficiency of heat transfer. On the contrary, an acute angle provides a slight drop in pressure but a less efficient heat transfer (see Fig. 1). A pair of plates comprises a package which may consist of different combinations of pairs depending on the predominance of the requirements of heat transfer efficiency or the minimization of pressure losses. Combinations of corrugation angles in the plates may vary (for example, $60^{\circ} / 60^{\circ}, 30^{\circ} / 60^{\circ}$, $30^{\circ} / 30^{\circ}$, etc.). The thickness of the plates is typically $0.5 \mathrm{~mm}$, and their dimensions are $0.4-3.5$ to $0.15-1.2 \mathrm{~m}$ [1]. The area of one plate can vary from 0.04 to $0.62 \mathrm{~m}^{2}$ and the nominal water consumption from 10 to $350 \mathrm{t} / \mathrm{h}$, the nominal power range varying from 700 to $16000 \mathrm{~kW}$ [1]. Flow channels between the adjacent plates have the dimensions of 6 to $12 \mathrm{~mm}$ [2-4]. In particular, flow channels in the collapsible Technology GEA "FREE FLOW" plate heat exchangers were increased to $12 \mathrm{~mm}$ in the absence of points of contact between the adjacent plates [2].

The corrugated surface of the channel-forming plates contributes significantly to the turbulence which determines the high efficiency of heat transfer even at low flow rates.

In accordance with [13], we assume the optimal design of the channel meeting the following basic requirements:

- highly specific surface;

- minimum hydraulic resistance;

- absence of stagnant zones;

- distribution uniformity of media (gas or liquid);

- turbulence.

The shape and geometric dimensions of channels are important but not exhaustive characteristics of plate heat exchangers. The relative position of these channels in the neighboring plates is also significant. From the viewpoint of the effectiveness of heat transfer in a plate apparatus and the compactness of these machines, analysis of the impact of the length of the input section of the hydrodynamic and thermal 


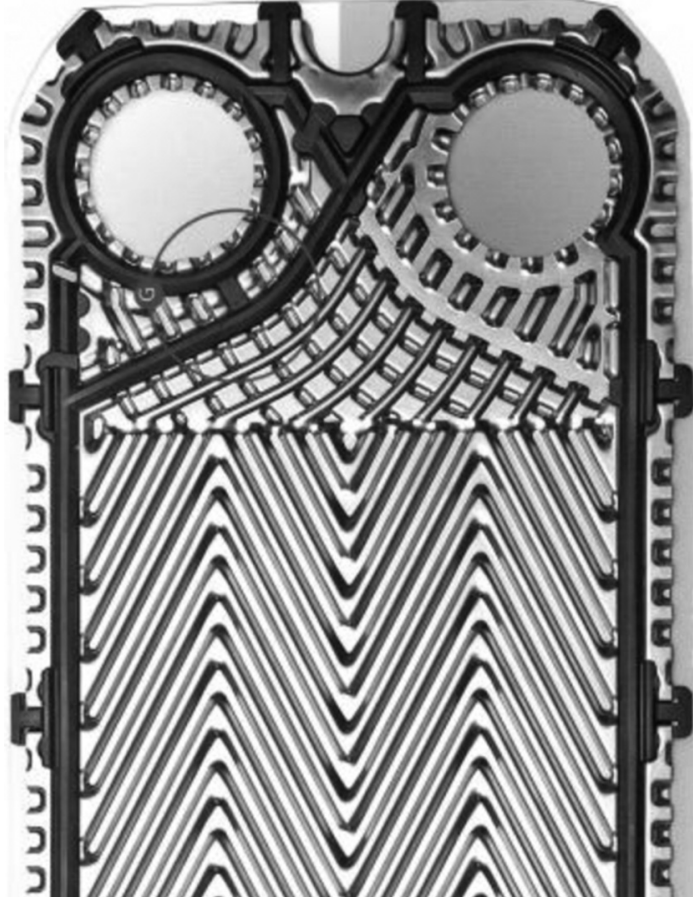

Fig. 1. Fragment of the Sondex plate group of a special "fish bone" design
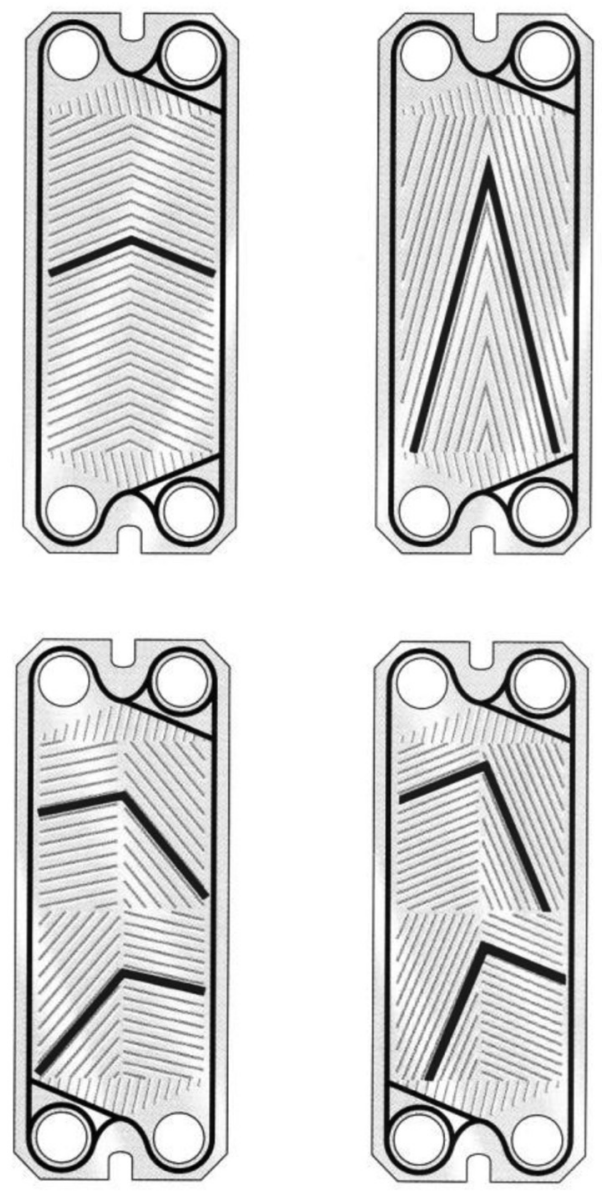

Fig. 2. Plate variants of ULTRAFLEX (GX) SWEP International $A B$ and TRANTER International AB companies stabilization of the flow in the channel also seems relevant $[5-11,14,15]$.

In this work, these characteristics are considered in channels of plate heat exchangers in their relationship. The influence of the geometry, relative position and length of channels of plate heat exchangers on hydrodynamics and heat transfer is analysed.

\section{THE IMPACT OF CHANNEL CROSS-SECTION}

Effect of channel shape on the size of the surface

Let us consider the effect of the geometric shape of channels on the value of the surface area $a$. The length of the channel was taken to be $H=1 \mathrm{~m}$; the wall thickness of the channel was neglected. Assume, for example, that the area of channels of different form is constant and equal to $9 \cdot 10^{-6} \mathrm{~m}^{2}$. The calculation results are summarized in Table 1.

Table 1 shows that the greatest surface of the same equal cross-section area allows developing a channel of a triangular cross-section. Channels of a square section have smaller values. The results are worst in hexagonal channels and in those of a circular cross-section.

Effect of the size of channels

We looked for a relationship between the specific surface $a$ and the value of the equivalent diameter of the channel $d_{e}$. Let us consider channels of triangular, circular and square cross sections. For simplicity, we assume that all channels are straight.

The basic geometric characteristics of the nozzle channel are determined from the relation [12]:

$$
a=\frac{4 \cdot \varepsilon}{d_{e}},
$$

here $a$ is the specific surface of the channel, $\mathrm{m}^{2} / \mathrm{m}^{3}, \varepsilon$ is the porosity of a single channel (in these cases, $\varepsilon=1$ ), $d_{e}$ is the equivalent channel diameter, $\mathrm{m}$, of the analogous hydraulic radius equal to one-fourth of the $d_{e}$ value.

$$
d_{e}=\frac{4 \cdot F}{P}
$$

here $F$ is the cross-section area of the channel, and $P$ is the wetted perimeter of the channel.

Calculations were performed for a conventional channel height $H=1 \mathrm{~m}$. The calculation results in a graphical dependence $a=\mathrm{f}\left(d_{e}\right)$ are shown in Fig. 3. As is evident from these data, the dependence $a=\mathrm{f}\left(d_{e}\right)$ for channels of triangular, circular and square cross-sections is described by one curve whose equation is

$$
a=3,999 \cdot d_{e}^{n},
$$

here $n=-1$.

Thus, increasing the size of the channel from $0.003 \mathrm{~m}$ to $0.012 \mathrm{~m}$ typical of plate heat exchangers, decreases the specific surface area 3.7 times. 
Table 1. Effect of channel shape on the size of its surface

\begin{tabular}{ccc|c}
\hline \multirow{2}{*}{ Parameter } & \multicolumn{2}{c}{ Form cross-sectional channel } \\
\cline { 2 - 4 } & Circular & Square & Triangular \\
\hline Party channel, $\mathrm{m}$ & $0.00338^{*}$ & 0.00186 & 0.003 \\
\hline Perimeter $P, \mathrm{~m}$ & 0.01063 & 0.01116 & 0.012 \\
\hline $\begin{array}{c}\text { The surface of the channel height } \\
h=1 \mathrm{~m} \mathrm{~S}, \mathrm{~m}^{2}\end{array}$ & 0.0106 & 0.0112 & 0.012 \\
\hline $\begin{array}{c}\text { Cross-section area } F, \mathrm{~m}^{2} \\
\begin{array}{c}\text { Value at the surface of channels of } \\
\text { different form, } \%\end{array}\end{array}$ & $9 \cdot 10^{-6}$ & $9 \cdot 10^{-6}$ & $9 \cdot 10^{-6}$ \\
\hline
\end{tabular}

* Diameter of the channel.

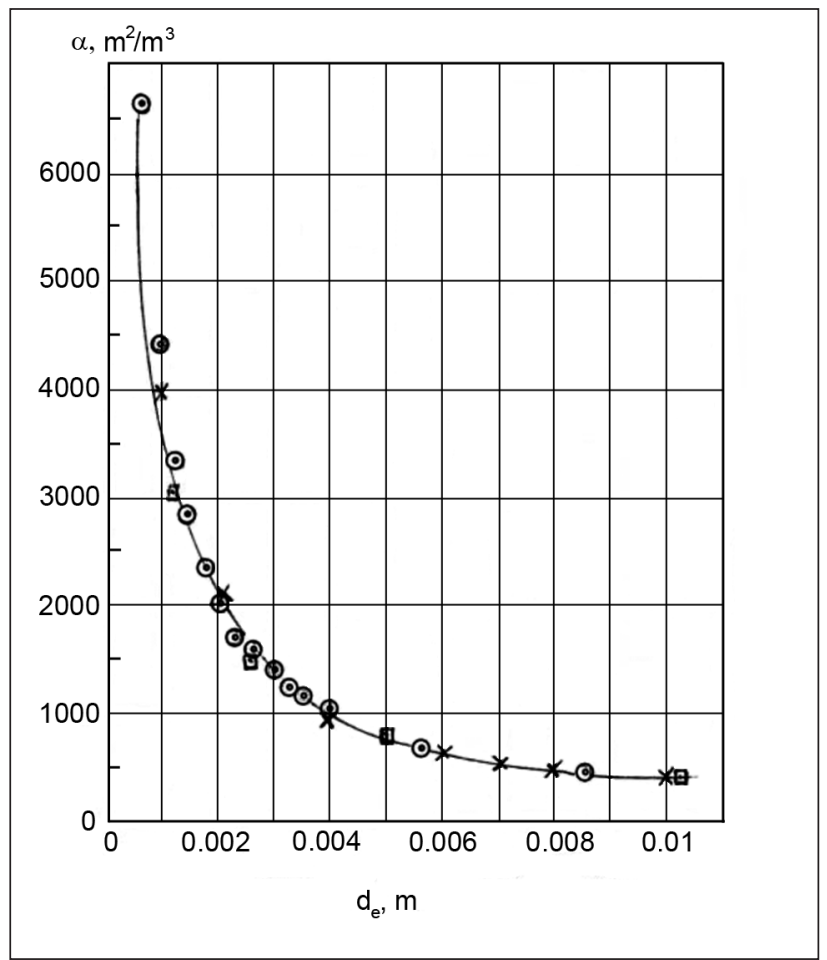

Fig. 3. The dependence $\alpha=f\left(d_{e}\right)$ of channels for different sections: $\odot$ - triangular, $x$ - round, $\square$-square

Effect of channel shape on flow hydrodynamics

A comparison of the velocity fields over the cross-section of channels of various shape shows that in channels of triangular and square cross-sections, in contrast to round, there are vortex and the so-called secondary flows caused by a threedimensional flow in them [6].

The velocity distribution in the channel cross-section is as follows.

For channels of a round cross-section:

$$
U=2 \cdot W_{0} \cdot\left[1-\left(\frac{R_{i}}{R}\right)^{2}\right],
$$

here $U$ is the current local value of velocity at a given crosssection of the channel, $\mathrm{m} / \mathrm{s} ; W_{0}$ is the average flow velocity in this section, $\mathrm{m} / \mathrm{s}, R_{i}$ is the current radius, $\mathrm{m}$, and $R$ is the channel radius, $m$.

For channels with a rectangular cross-section [7]:

$$
U=\left(\frac{3}{2}\right) \cdot W_{0} \cdot\left[1-\left(\frac{2 y}{\delta}\right)^{2}\right],
$$

here $y$ is the current distance from the channel wall, $\mathrm{m}$, and $\delta$ is the width of the rectangular slot, $\mathrm{m}$.

For channels of triangular cross-section.

$$
U=45 \cdot W_{0} \cdot\left[\left(\frac{x}{h}-1\right) \cdot\left[\left(\frac{y}{h}\right)^{2}-\frac{1}{3} \cdot\left(\frac{x}{h}\right)^{2}\right]\right],
$$

here $h$ is the height of an equilateral triangle, $\mathrm{m}$, and $x, y$ are the current values in the coordinate axes.

The axis of symmetry of the cross-section of the channel in the form of an equilateral triangle passes through the middle of the base of the triangle, and the base of the triangle $b=\frac{2 h}{\sqrt{3}}$.

For a channel plate heat exchanger, in the case of channels with a cross-section of triangular shape with a strong contraction in the flow area of sharp corners in the area of narrowing there may exist, even in the laminar flow, the Reynolds number (Re) several times greater than the critical number Re characteristic of a circular channel. At the same time, the rest of the section of the triangular channel flow can be turbulent [6].

Relationships between the maximum $W_{\max }$ and the average flow velocity $W_{0}$ for channels of a circular section are shown in Fig. 4.

For flat channels with a laminar flow regime, the value of the ratio between the maximum and the average flow rates is higher than that for channels of a round cross-section: $W_{0}=0.666 \cdot W_{\max }$ in a flat and $W_{0}=0.5 \cdot W_{\max }$ in a circular channel.

We estimated the effect of channel shape on the coefficient of hydrodynamic resistance. The differential static pressure in the channels is calculated by the known formula [8]:

$$
\Delta P=\xi \cdot \frac{\rho \cdot W_{0}^{2}}{2} \cdot \frac{L}{d_{e}},
$$

here $\zeta=$ the coefficient of hydrodynamic resistance, $\rho$ is the density of gas, $\mathrm{kg} / \mathrm{m}^{3} ; W_{0}$ is the average speed of medium flow per total cross-section of an empty channel, $\mathrm{m} / \mathrm{s}, L$ is the length of the calculated section of the channel, $\mathrm{m}$, and $d_{e}$ is the equivalent channel diameter, $\mathrm{m}$. 


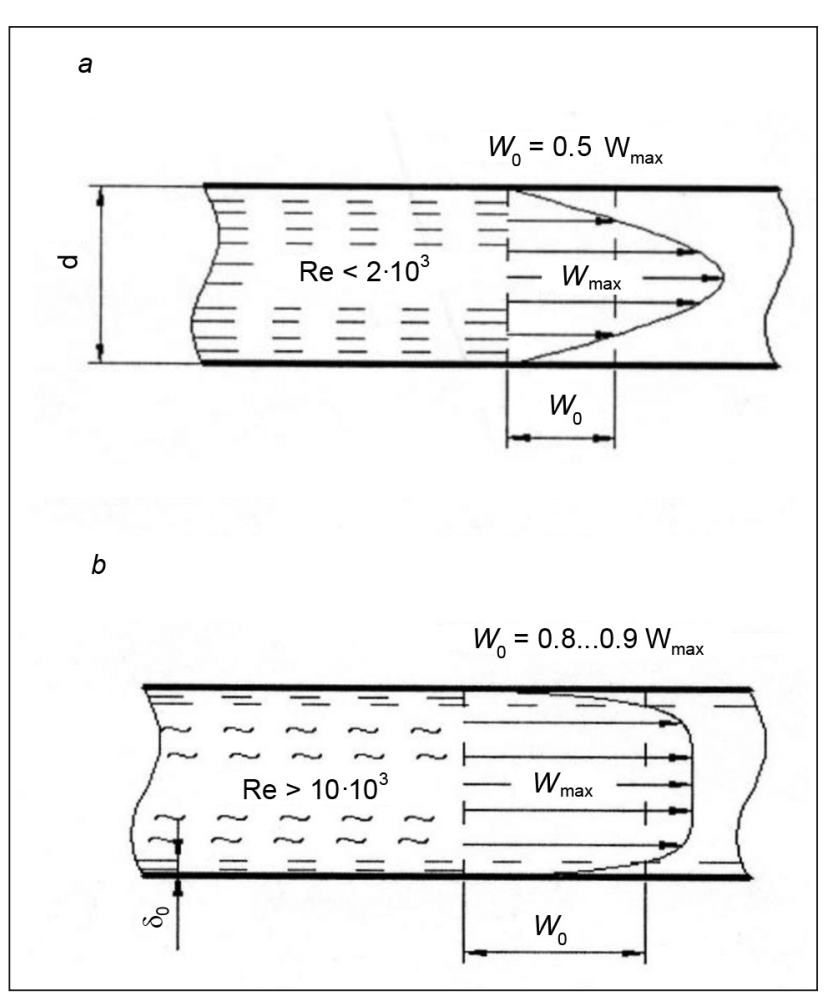

Fig. 4. Distribution of local flow velocity in the channel of circular cross-section in the laminar ( $a$ ) and turbulent $(b)$ flow regimes

For a fully developed flow in channels of various crosssection, we have $[6,8]$ :

$$
\xi=\frac{B}{\operatorname{Re}}
$$

here $\operatorname{Re}=\frac{W_{0} \cdot d_{e}}{v}$,

where $v$ is the kinematic viscosity of the air, $\mathrm{m}^{2} / \mathrm{s}$.

The coefficient $B$ values in equation (8) for channels of various cross-sections are shown in Table 2.

The results of calculating the coefficient of hydrodynamic resistance $\zeta$ for channels of various shape with $W_{0}=2.0 \mathrm{~m} / \mathrm{s}, d_{e}=0.005 \mathrm{~m}, v=15.06 \cdot 10^{-6}\left(\mathrm{~m}^{2} / \mathrm{s}\right)[9]$ are presented below. In this case, $\operatorname{Re}=664$ at the laminar flow regime; therefore:

for a square channel:

$$
\xi=\frac{56.9}{664}=0.086,
$$

for a channel of a round cross-section:

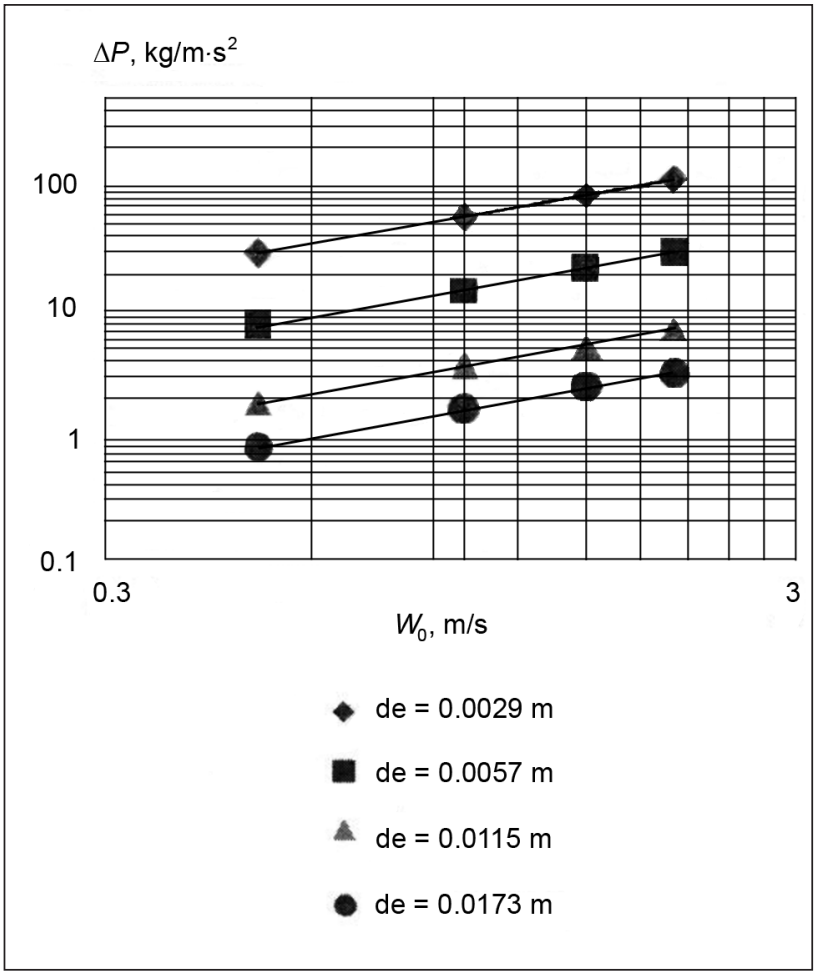

Fig. 5. Dependence of pressure loss $\Delta P$ of the average flow velocity of the gas medium $W_{0}$ for channels of triangular cross-section

$$
\xi=\frac{64}{664}=0.096,
$$

for a channel of a triangular cross-section:

$$
\xi=\frac{53}{664}=0.079 \text {. }
$$

Thus, the hydrodynamic resistance of channels of square and triangular sections (with an identical part of the typical cross-section) is quite similar.

By formula (7) we calculated the pressure loss $\Delta P$ for channels of square and triangular cross-sections with the size $5.0 \times 5.0 ; 10.0 \times 10.0 ; 20.0 \times 20.0$ and $30.0 \times 30.0 \mathrm{~mm}$. The wall thickness of the channels was $\delta=0.3 \mathrm{~mm}$ and the height was assumed to be $1 \mathrm{~m}$. The air density $\rho=1.205$ $\mathrm{kg} / \mathrm{m}^{3}$, the kinematic viscosity of air $v=15.06 \cdot 10^{-6}\left(\mathrm{~m}^{2} / \mathrm{s}\right)[9]$. The calculation results are plotted in the form of dependency $\Delta P=f\left(W_{0}\right)$ (see Figs. 5 and 6). These charts show that the resistance at the identical values of $d$ is lower in channels of a triangular cross-section; this can be attributed to a smaller number of acute angles in the triangular cross-section, which form the secondary vortex flow.

Table 2. The coefficient $B$ in equation (8)

\begin{tabular}{ccc|c|c}
\hline Cross-section of channel & Rectangular & Circular & Square & Triangular \\
\hline $\begin{array}{c}\text { Coefficient } B \text { in } \\
\text { equation (8) }\end{array}$ & 64 & 96 & 56,9 & 53 \\
\hline
\end{tabular}


$\Delta P, \mathrm{~kg} / \mathrm{m} \cdot \mathrm{s}^{2}$

100

10

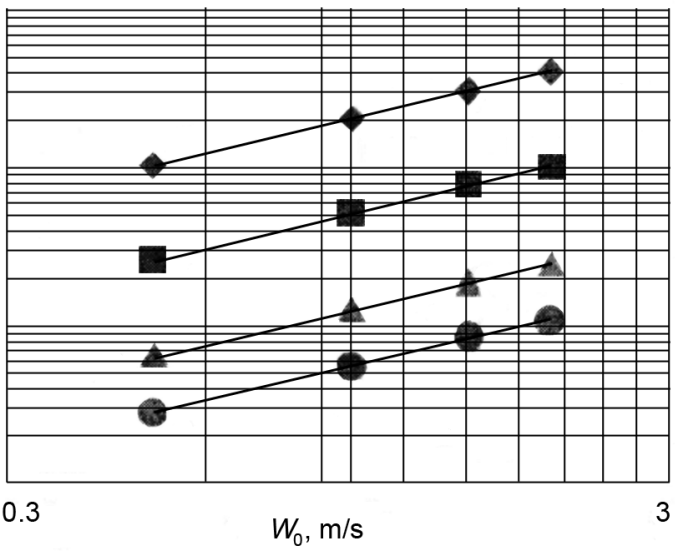

- de $=0.005 \mathrm{~m}$

- $\mathrm{de}=0.01 \mathrm{~m}$

A $\mathrm{de}=0.02 \mathrm{~m}$

- de $=0.03 \mathrm{~m}$

Fig. 6. Dependence of pressure loss $\Delta P$ of the average flow velocity of the gas medium $W_{0}$ for channels of square section

\section{EXPANSION OF HYDRODYNAMIC FLOW STABILIZATION}

The modern theory of the boundary layer gives the following representations of the length of the input section of the hydrodynamic stabilization of a flow. The basic idea of stabilizing the flow, as is known, is to perform the correlation $\partial W_{x} / \partial x=0$. From the standpoint of obtaining the maximum effect of heat transfer intensification, of greatest interest is the first part of the input area. In this zone, the boundary layers are not closed after entering the channel (Fig. 7). It is in this zone Z that abrupt changes in hydraulic resistance and in other parameters of the flow occur. The hydraulic resistance of the flow in this area improves in comparison with the subsequent part of the channel by $9-10 \%[11,16]$. However, within the selected zone $\mathrm{Z}$, also the heat transfer coefficient $\alpha$ along the pipe changes (Fig. 7). The question whether these changes in the extreme parameters of the system are a positive or a negative phenomenon for the implementation of the processes of heat transfer in a plate apparatus remains relevant. Since there is a difference of opinions, we shall discuss this issue in more detail.

In [17], it has been suggested that an increase in the hydraulic resistance of channels due to additional loss of pressure in the inlet and outlet sections reduces the heating efficiency.

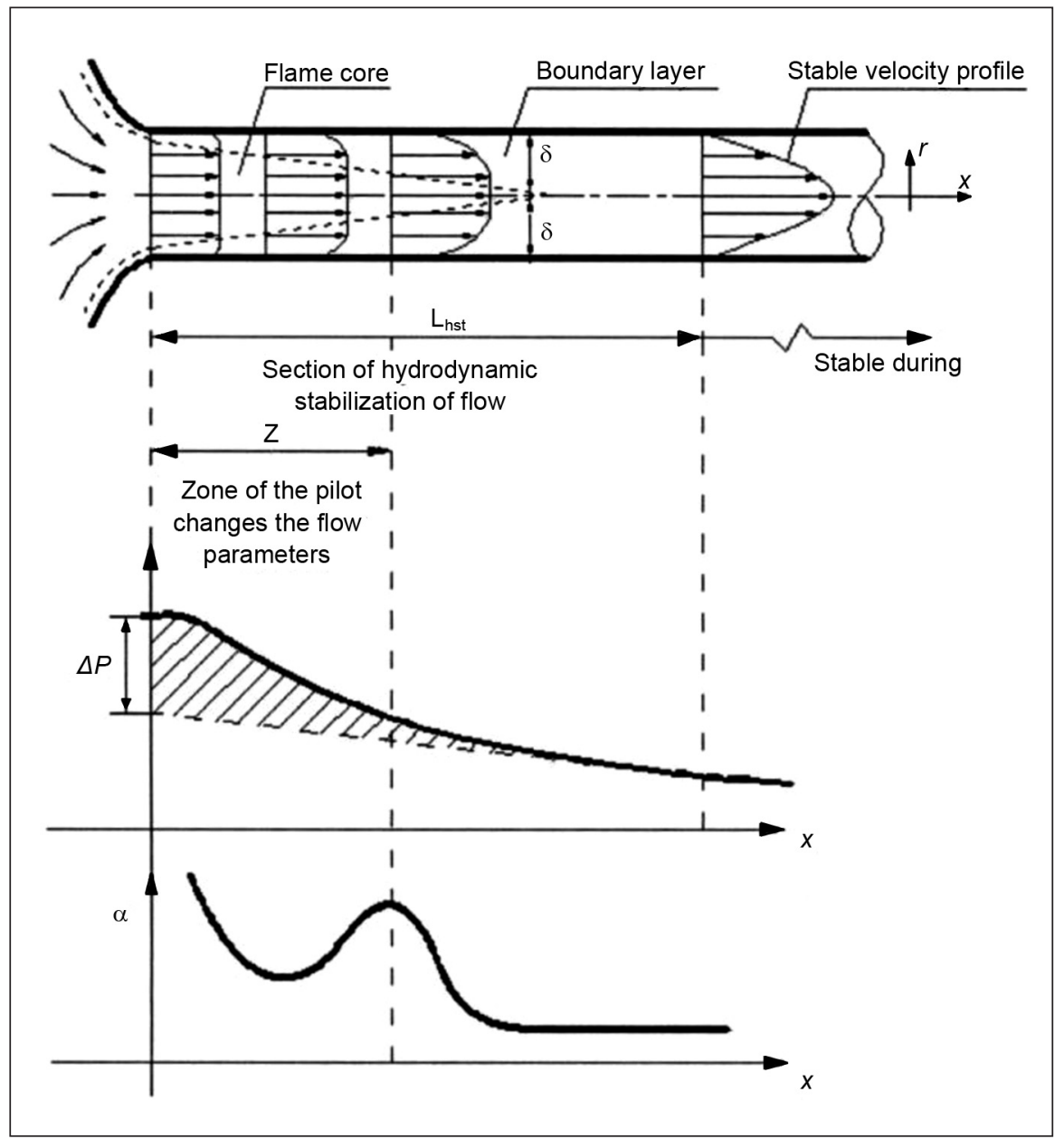

Fig. 7. Formation of a steady velocity profile of gas flow in the initial section of the channel by changing the pressure loss $\Delta P$ and the heat transfer coefficient $a$ along the channel $x$ 


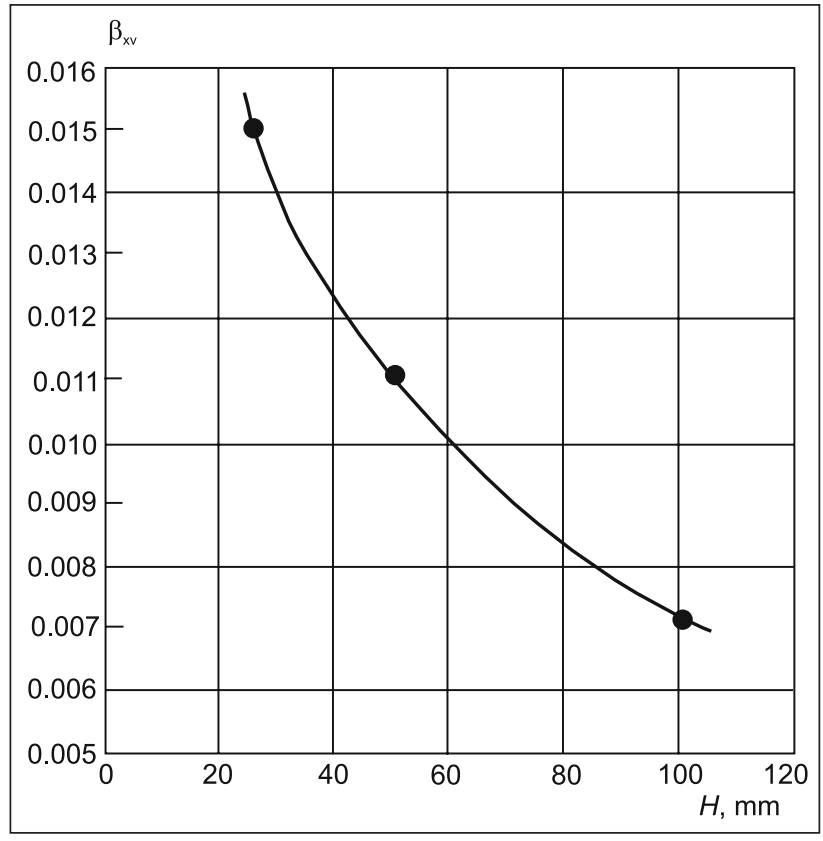

Fig. 8. Dependence of mass transfer coefficient in the liquid phase $\beta_{p v}$ Sulzer packing on the height of a single package $H$. The load on the liquid $q=10 \mathrm{~m}^{3} /\left(\mathrm{m}^{2} \cdot \mathrm{h}\right)$

In [18], experimentally it has been demonstrated the opposite - a decrease in the height of single nozzle $H$ packages; ceteris paribus, the value of the mass transfer coefficient $\beta_{x y}$ packing Sulzer increases substantially, reaching the maximum value at $H=25 \mathrm{~mm}$ (see Fig. 8).

Experimental data [19] confirm the data presented in [18]. As a result, studies of the process of evaporative cooling of water in a regular packing film type, made of vertically mounted boards [19], have shown that the coefficient $A_{0}$, characterizing the efficiency of the process, the type, design and geometric dimensions of the nozzle, depends on the height of the nozzle $H$. The coefficient $A_{0}$ is a constant factor in the well-known empirical formula for calculating the mass transfer coefficients $\beta_{x v}[19]$ :

$$
\beta_{p v}=\frac{A_{0}}{P_{\delta}} \cdot\left(\gamma_{L} \cdot q_{L}\right)^{1-n} \cdot\left(\gamma_{a} \cdot W_{0}\right)^{n},
$$

where $\beta_{p v}=$ volumetric mass transfer coefficient, $\mathrm{kg} / \mathrm{m}^{3}$. .h. atm;

$A_{0}$ is a constant factor, $\mathrm{m}^{-1}$;

$P_{\delta}$ is barometric pressure, atm;

$\gamma_{L}$ is the proportion of water, $\mathrm{kg} / \mathrm{m}^{3}$;

$\gamma_{a}$ is the proportion of air, $\mathrm{kg} / \mathrm{m}^{3}$;

$n$ is exponent;

$q_{L}$ is the density of irrigation, $\mathrm{m}^{3} /\left(\mathrm{m}^{2} \cdot \mathrm{h}\right)$;

$W_{0}$ is air velocity in the calculation of the total cross-section of empty vehicle, $\mathrm{m} / \mathrm{s}$.

The results discussed in [19] are presented in Fig. 9 which shows that in the the nozzle height interval from $H=0.9 \mathrm{~m}$ up to $H=1.7 \mathrm{~m}$ the change in $A_{0}$ is $30-60 \%$ and in the range of $H=1.7 \mathrm{~m}$ up to $H=2.5 \mathrm{~m}$ only $10-25 \%$. Thus, by increa-

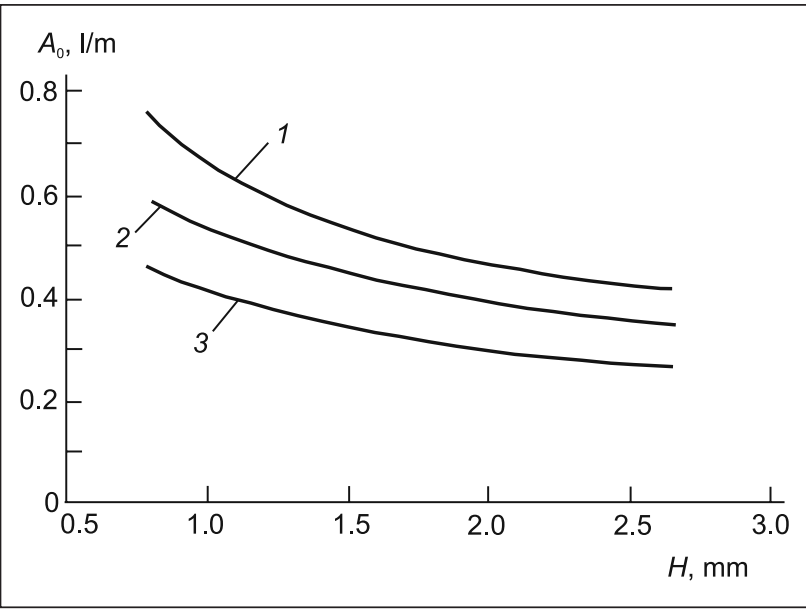

Fig. 9. Dependence $A_{0}=f(H)$ of the data of [19]. The distance between the nozzle screens in the world practice: $1-15 \mathrm{~mm}, 2-25 \mathrm{~mm}, 3-35 \mathrm{~mm}$

sing the height of the filling, the effect of $H$ on the parameter $A_{0}$ is reduced.

In [14], the following expression is proposed for estimating the area of the zone $Z$ (see Fig. 7) in which there occur extreme changes in the flow parameters:

$$
Z=A \cdot\left(L_{h s t} / d_{e}\right)
$$

here: $d_{e}=$ see equation (2);

$A=0.33$ (the coefficient);

$L_{h s t}=$ the length of the section of hydrodynamic stabilization of flow in the channel.

For a laminar flow:

$L_{h s t}=m \cdot d_{e} \cdot \operatorname{Re}_{d e}$

For the turbulent flow regime:

$L_{h s t}=k \cdot d_{e} \cdot \operatorname{Re}_{d e^{\mathrm{n}}}^{\mathrm{n}}$

where $m=0.03-0.065$;

$k=4.4$;

$n=1 / 6$.

The Reynolds number:

$\operatorname{Re}_{d e}=\frac{\omega \cdot d_{e}}{v}$,

where $\omega$ is the speed of the current environment, $\mathrm{m} / \mathrm{s}$;

$v$ is kinematic viscosity, $\mathrm{m}^{2} / \mathrm{s}$.

In equations (14)-(16), the impact of the channel shape is shown by the parameter $d_{e}$. Using these equations, the length of the input section of hydrodynamic stabilization of flow $L_{h s t}$ as well as the area of the zone $Z$ for channels with the value equivalent to the diameter of $d_{e} 5-40 \mathrm{~mm}$ have been calculated. These results are partially presented in Table 3 and shown in Figs. 10 and 11. Initial data taken for the calculation: gas - air, $T=20^{\circ} \mathrm{C}, v=15.06 \cdot 10^{-6} \mathrm{~m}^{2} / \mathrm{s}$. 
Table 3. The length of the zone $Z$ for channels of circular section for different $R \boldsymbol{e}_{d e}$ values

\begin{tabular}{|c|c|c|c|c|c|}
\hline$d_{e^{\prime}} \mathrm{m}$ & $\omega, \mathrm{m} / \mathrm{s}$ & $R \boldsymbol{e}_{d e}$ & $L_{h s^{\prime}} \mathrm{m}$ & $L_{h s t} / d_{e}$ & $Z$ \\
\hline \multirow{3}{*}{0.005} & 1.0 & 332 & 0.083 & 16.6 & 5.47 \\
\hline & 2.0 & 664 & 0.166 & 33.2 & 10.95 \\
\hline & 3.0 & 996 & 0.249 & 49.8 & 16.43 \\
\hline \multirow{3}{*}{0.010} & 1.0 & 664 & 0.332 & 33.2 & 10.95 \\
\hline & 2.0 & 1328 & 0.664 & 66.4 & 21.91 \\
\hline & 3.0 & 1992 & 0.996 & 99.6 & 32.86 \\
\hline \multirow{3}{*}{0.015} & 1.0 & 996 & 0.747 & 49.8 & 16.43 \\
\hline & 2.0 & 1992 & 1.494 & 99.6 & 32.86 \\
\hline & 3.0 & 2988 & 0.25 & 16.6 & 5.47 \\
\hline \multirow{3}{*}{0.020} & 1.0 & 1328 & 1.328 & 66.4 & 21.91 \\
\hline & 2.0 & 2656 & 0.327 & 16.35 & 5.39 \\
\hline & 3.0 & 3984 & 0.35 & 17.5 & 5.77 \\
\hline
\end{tabular}

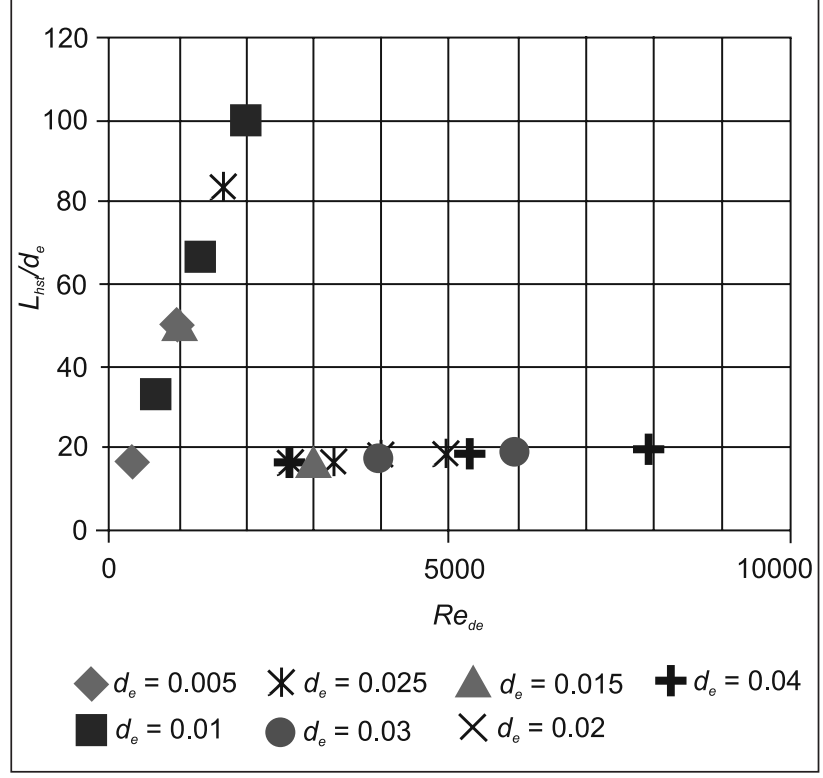

Fig. 10. Dependence of the simplex $L_{h s t} / d_{e} R e_{d e}$ of the Reynolds number for different $d$ values in our calculations

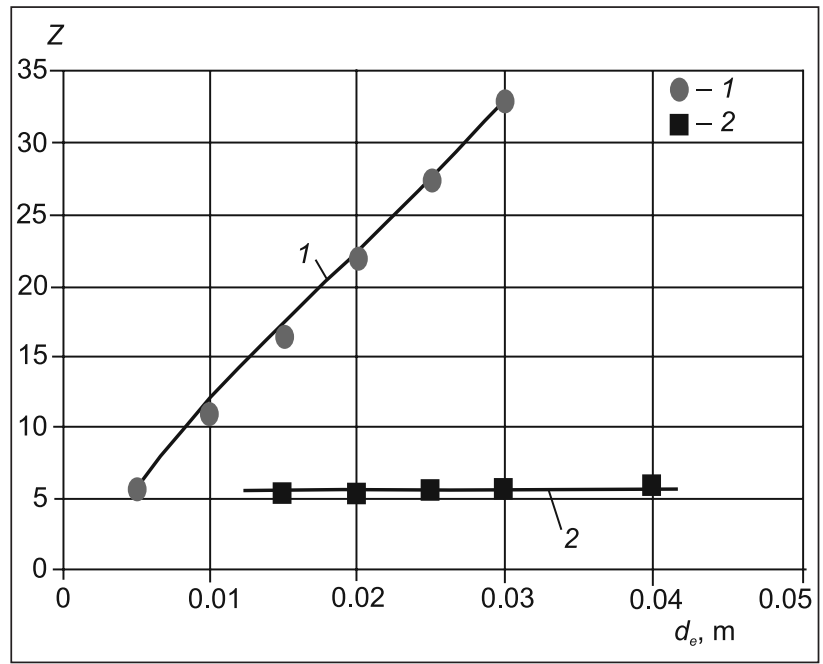

Fig. 11. Calculated $Z=f\left(d_{e}\right)$ from equations (14)-(17) for Reynolds numbers: $1-$ from $R e_{d e}=332$ to $R e_{d e}=2000 ; 2-$ from 2988 to $R e_{d e}=R e_{d e}=7968$
As is evident from the results of calculations presented in Table 3 and Fig. 11, with an increase in the $d_{e}$ values from $5 \mathrm{~mm}$ to $30 \mathrm{~mm}$ the length of the laminar flow zone $\mathrm{Z}$ increases from 5.47 to $32.86 \mathrm{~mm}$. In the turbulent flow regime with an increase of the channel $d_{e}$ from $15 \mathrm{~mm}$ to $20 \mathrm{~mm}$ or more, the dependence $Z=f\left(d_{e}\right)$.

The above analysis and the results of the calculations show a possibility of choosing the optimal length of the channels of plate heat exchangers, based on the length of the zone $Z$.

The relationships between long sections of the hydrodynamic and thermal stabilization of the laminar flow regime and at the wall temperature $t_{c}=$ const are as follows:

$$
\frac{L_{t s t}}{L_{h s t}}=\frac{0.05 \cdot d_{e} \cdot \operatorname{Re} \cdot P_{r}}{0.03 \cdot d_{e} \cdot \operatorname{Re}} \approx 1.7 \cdot \operatorname{Pr},
$$

here $L_{\text {tst }}$ is part of the thermal stabilization of the flow, and $\operatorname{Pr}=\frac{v}{\alpha}$ is the Prandtl number.

As for air (or diatomic gases), $P r=0.71$; the relationship (18) in this case is:

$$
L_{t s t}=1.21 \cdot L_{h s t^{*}}
$$

The proposed equations (14)-(17), (19) can be used in a constructive design of plate heat exchangers.

\section{ANALYSIS OF INFLUENCE OF MUTUAL ARRANGEMENT OF RELATED PIPES OF COMPLICATED GEOMETRY BETWEEN THE NEIGHBOURING CORRUGATED SHEETS}

The hypothesis of a qualitative analogy between the hydrodynamic flow streams in the plate heat exchangers and mixing

It is known that heat transfer from one carrier to another in plate heat exchangers occurs by thermal conduction through a solid wall. In a mixing heat exchanger, heat is transferred by a direct contact of gas and liquid flows on the wall of the channels through which a thin film of the liquid gravitationally flows down. 
A common feature of the two types of heat exchangers is the geometry of the channels of a complex shape. Package nozzles are used in mixing heat exchangers (cooling towers), and the form of channels between adjacent corrugated sheets in a package of such nozzles is shown in Figs. 12 and 13.

From the standpoint of hydrodynamic difference between the two types of heat exchangers, essential is the presence in the channel of the two phases in contact with each other in a countercurrent mode. Since, however, in mixing heat exchangers the liquid phase in the form of a thin film on the walls of the channel occupies only a small part of the cross-section of the channel, then, neglecting the liquid film thickness [39] and waves on its surface [41], it is clear that the proposed analogy between the conditions of flux flow in the channels of mixing and plate heat exchangers is qualitative and of purely hydrodynamic nature. We use the proposed qualitative analogy to justify the possibility of transferring some of the qualitative patterns obtained by experiment in the channels of mixing heat exchangers to the channels of plate heat exchangers.

Figure 12 shows that a nozzle represents packets or blocks consisting of corrugated steel sheets interconnected by pins so that each successive sheet is rotated by $90^{\circ}$ relative to the preceding one. These channels are formed at the height of the nozzle system of intersecting channels of a triangular crosssection from each of the contiguous corrugated sheets so as to change their configuration, and are alternately of triangular and rhombic cross-section.

Determination of the optimal angle of corrugations in adjacent plates of a heat exchanger from the results of experiments in the process of evaporative cooling

It is known that a system of differential equations of heat and mass transfer, which describe the process of evaporative cooling towers in the irrigation area, consists of two rates of return - the heat transfer coefficient $\alpha_{v}$ and the volumetric mass transfer coefficient $\beta_{p v}$. In this case, there is a physical relation between these rates of return [21]:

$$
\alpha_{v} / \beta_{p v}=1.65 \mathrm{kj} /\left(\mathrm{kg} \cdot{ }^{\circ} \mathrm{C}\right) \text {, }
$$

here $\alpha_{v}$ is the volumetric heat transfer coefficient, attributable to the temperature difference in cooling tower water and cooling air, $\mathrm{kJ} /\left(\mathrm{kg} \cdot{ }^{\circ} \mathrm{C}\right)$;

$\beta_{p v}$ is the volumetric mass transfer coefficient, referred to the difference of partial pressures, divided by the barometric pressure, $\mathrm{kg} /\left(\mathrm{m}^{3} \cdot \mathrm{s}\right)$.

Numerically, the ratio (20) follows from the psychrometric formula for the Assman aspiration psychrometer [23].

In carrying out the aerial thermal testing of various designs of regular attachments in blocks of corrugated plates, the coefficient $\beta_{p v}$ is determined by the results of tests accor-

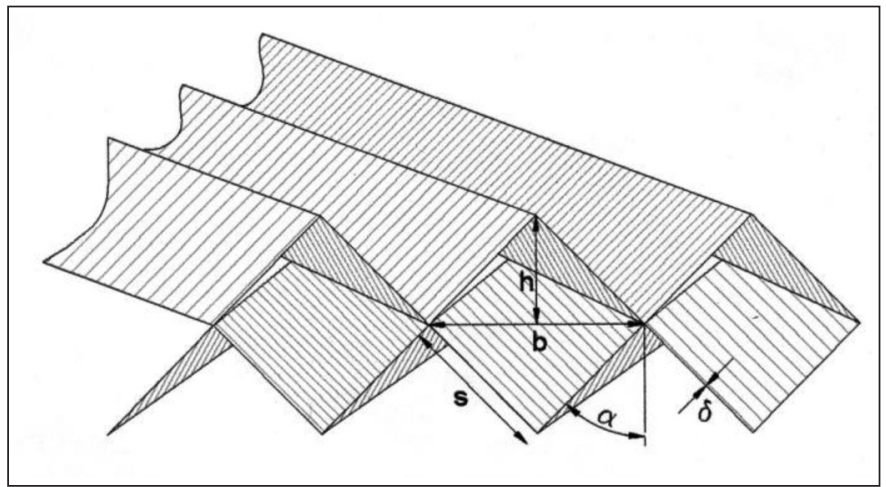

Fig. 12. Geometrical parameters of corrugated nozzle: $h$ - height; $b$ - length of the base; $s$ - side length; $\delta$ - sheet thickness; $a$ - the angle of inclination to the horizon

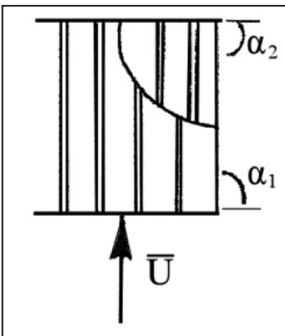

$\alpha_{1}=\alpha_{2}=90^{\circ}$

$\beta=0^{\circ}$

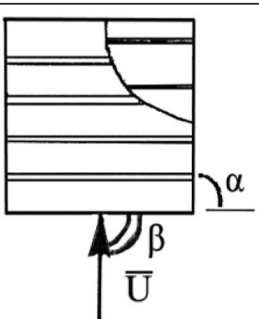

2

$\alpha_{1}=a_{2}=0^{\circ}$

$\beta=90^{\circ}$

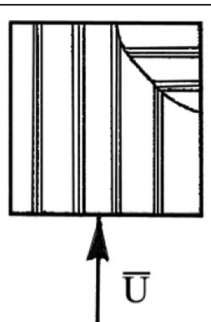

3

$a_{1}=90^{\circ}, a_{2}=0^{\circ}$

$\beta=45^{\circ}$

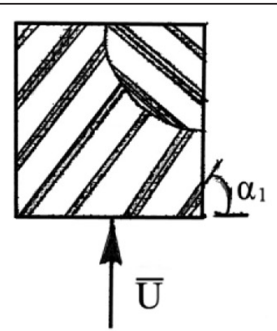

4

$\alpha_{1}=\alpha_{2}=60^{\circ}$

$\beta=30^{\circ}$

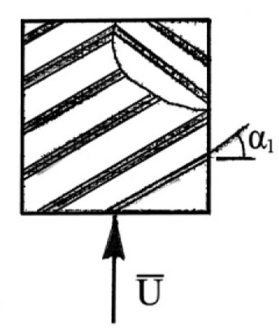

5

$\alpha_{1}=\alpha_{2}=30^{\circ}$

$\beta=60^{\circ}$

Fig. 13. Scheme of the angles of nozzle blocks: $\alpha$ - corrugation angle; $\beta$ - angle of attack; $\bar{U}$ - air flow velocity vector 
ding to the currently applied method $[22,23]$, and the $\alpha_{v}$ coefficient is calculated from equation (19).

The equations for calculating the coefficients $\beta_{p v}$ and $\alpha_{v}$ are as follows:

$$
\begin{aligned}
& \alpha_{v}=\frac{\alpha \cdot F}{V}, \\
& \beta_{p v}=\frac{\beta_{p} \cdot F}{V} .
\end{aligned}
$$

We consider the volume $V$ in which the free surface of liquid is equal to $F$ and the average difference in temperature and partial pressures are, respectively, $(t-V)_{c p}$ and $\left(P^{\prime \prime}-P\right)_{c p^{\prime}}$.

Hence it follows that these coefficients depend on the physical properties and velocity of the flowing medium, channel configuration (geometry), the size and condition of the washed surface. Given the above hypothesis about the quality of the hydrodynamic analogy between the current flows in plate, as well as taking into account the fundamental analogy between heat and mass transfer, the results of the evaporative cooling of water circulating in a mixing heat exchanger - a cooling tower at the nozzle, made in the form of blocks of vertical corrugated sheets - may be used for the qualitative prediction of hydrodynamic flow in channels of complex geometry in plate heat exchangers.

The basic design parameter of a block nozzle is the slope of adjacent corrugation sheets, which varies from $0^{\circ}$ to $90^{\circ}$. The published experimental data on the effect of the tilt angle are contradictory. For example, in [24] it is argued that a high nozzle should form straight, possibly vertical channels. In [25-30], oblique nozzle corrugations are preferred. Most manufacturers are promoting the world market caps made from plates with oblique corrugations [31-35]. Contrary to the opinion of [24] based on their own experimental data, the authors of [36] conclude that the use of nozzles with vertical channels is unlikely to be economically justified. Thus, assessing the impact of nozzle geometry on the efficiency of heat and mass transfer is an important task.

Unfortunately, the extensive experimental work reported in [36] shows that a comparison of nozzles with a different angle of corrugation is qualitative in nature and seems to result from the authors' approach to the geometric parameter - the angle to the horizontal corrugations. This geometric parameter did not allow the authors of [36] to compare the results. Meanwhile, materials of the fundamental research carried out by Arefyev [36] are of considerable interest. An important advantage of the experimental data presented in [36] is the fact that all types of attachments in this work were studied in identical conditions, at one stand and by one technique, thus excluding the influence of the scale factor.

Below, we present the results of our analysis and synthesis of the experimental results reported in [36], in contrast to [36], in the present study we used not the geometrical parameter of the inclination of corrugation plates to the hori- zontal plane $\alpha$ as is adopted in aerodynamics, but the angle of attack of the incoming air stream $\beta$, which allowed us to obtain a satisfactory generalization.

The pending construction of the nozzle blocks indicating circuit designations of the corresponding angles is presented in Fig. 13. Due to the specular corrugation of adjacent sheets of a regular nozzle relative to each other, the estimated angle of attack for this unit was defined as the arithmetical mean for two adjacent sheets.

In describing the processes of evaporative cooling of water in the cooling tower, the Merkel number is used [37]:

$$
M_{e}=\frac{\beta_{X V} \cdot H}{G_{w}},
$$

here $\beta_{X V}$ is the volume coefficient of heat and mass transfer, divided by the difference in moisture content, $H$ is the height of the block nozzle, $\mathrm{m}$, and $G_{w}$ is the mass flow rate of cooling circulating water in the cooling tower:

$$
G_{w}=\frac{\rho_{w} \cdot q_{L}}{3600},
$$

here $\rho_{w}$ is water density, $\mathrm{kg} / \mathrm{m}^{3}$, and and $q_{w}$ is the density of irrigation, $\mathrm{m}^{3} /\left(\mathrm{m}^{2} \cdot \mathrm{h}\right)$.

According to [36, 38], the volume coefficient of heat and mass transfer $\beta_{X V}$ can be defined as follows:

$$
\beta_{X V}=A \cdot \lambda^{m} \cdot q_{w^{\prime}}
$$

here $\lambda=\frac{q_{a}}{q_{w}}$ is a relative air flow, $\mathrm{kg} / \mathrm{kg} ; q_{a}$ is the air mass

flow rate, $\mathrm{kg} /\left(\mathrm{m}^{2} \cdot \mathrm{s}\right) ; q_{w}$ is the irrigation density, $\mathrm{kg} /\left(\mathrm{m}^{2} \cdot \mathrm{s}\right)$; $A$ is the coefficient characterizing the influence of design features of the nozzle block on its cooling capacity, i. e. the efficiency of the nozzle geometry, $\mathrm{m}^{-1} ; m$ is an exponent.

Based on numerous experiments, we have assumed that the coefficient $A$ and the exponent $m$ in equation (24) are constants for block attachments of a given geometric design. Therefore, it is convenient to base a comparison of different designs on the coefficient $A$ in equation (24).

A comparison of various attachments may be performed in the following aspects $[24,40]$ :

- as a ratio of the hydraulic resistance of the nozzle to the attainable efficiency of evaporative cooling of water circulating in the cooling tower;

- as the effect of the cooling process on energy costs.

In this study, we have used two methodological approaches - the balance $\frac{\xi}{A}$ and $\frac{A}{\xi}$ in which $\zeta$ is the coefficient of hydraulic resistance of dry unirrigated nozzle, referred to the height of the nozzle, $\mathrm{m}^{-1}$, and $A$ is the factor in equation (24).

In a mixed system of units (MKGSS-SI), the coefficient $\zeta$ has the following expression:

$$
\xi=\frac{2 \Delta P \cdot g}{\rho_{a} \cdot W_{0}^{2}},
$$


Ta ble 4. Results of our processing of experimental data of [36]

\begin{tabular}{|c|c|c|c|c|c|c|c|}
\hline $\begin{array}{c}\text { Scheme of block tips } \\
\text { (Fig. 13) }\end{array}$ & $\begin{array}{c}\text { Angle } \\
\beta,^{\circ}\end{array}$ & $\begin{array}{c}\text { Height of block } \\
\text { nozzle } H, \mathrm{~m}\end{array}$ & $A, \mathrm{~m}^{-1}$ & $A \cdot H$ & $\zeta, 1 / m$ & $\frac{\xi}{A}$ & $\frac{\xi}{A \cdot H}, \mathrm{~m}^{-1}$ \\
\hline \multirow[t]{3}{*}{1} & 0 & 2.85 & 0.305 & 0.869 & 3.00 & 9.836 & 3.45 \\
\hline & \multirow{4}{*}{90} & 0.70 & 0.890 & 0.623 & 21.86 & 24.56 & 35.09 \\
\hline & & 1.40 & 0.540 & 0.756 & 21.86 & 40.48 & 28.92 \\
\hline \multirow[t]{5}{*}{2} & & 2.10 & 0.450 & 0.945 & 21.86 & 48.58 & 23.13 \\
\hline & & 2.80 & 0.390 & 1.092 & 21.86 & 56.05 & 20.00 \\
\hline & \multirow{4}{*}{45} & 0.70 & 1.170 & 0.819 & 12.38 & 10.58 & 15.12 \\
\hline & & 1.40 & 0.630 & 0.882 & 12.38 & 19.65 & 14.04 \\
\hline & & 2.10 & 0.580 & 1.218 & 12.38 & 21.35 & 9.67 \\
\hline \multirow[t]{4}{*}{3} & & 2.80 & 0.540 & 1.512 & 12.38 & 22.33 & 8.19 \\
\hline & \multirow{6}{*}{30} & 1.050 & 0.805 & 0.888 & 5.51 & 6.85 & 6.20 \\
\hline & & 1.575 & 0.585 & 0.921 & 5.51 & 9.42 & 5.98 \\
\hline & & 2.100 & 0.360 & 0.756 & 5.51 & 15.31 & 7.29 \\
\hline \multirow[t]{3}{*}{4} & & 2.625 & 0.343 & 0.900 & 5.51 & 16.064 & 6.12 \\
\hline & & 1.575 & 0.690 & 1.08675 & 15.43 & 22.36 & 14.2 \\
\hline & & 2.100 & 0.515 & 1.0815 & 15.43 & 29.96 & 14.26 \\
\hline 5 & 60 & 2.625 & 0.470 & 1.23375 & 15.43 & 32.83 & 12.51 \\
\hline
\end{tabular}

here, $\Delta P=\mathrm{kgs} / \mathrm{m}^{2}$ or $\mathrm{mm}$ of the water column is the total pressure loss in the nozzle, $\left[\rho_{a}\right]=\mathrm{kg} / \mathrm{m}^{3}$ is the gas flow density (from air $\rho_{a}=1.2 \mathrm{~kg} / \mathrm{m}^{3}$ at $10^{\circ} \mathrm{C}$ ), $W_{0}=\mathrm{m} / \mathrm{s}$ is the expected velocity of air in the full cross-section of the empty vehicle; $[g]=\mathrm{m} / \mathrm{s}^{2}$ is the acceleration of gravity.

The results of our processing of the experimental data of [36] using the angle of attack $\beta$ as a geometric parameter of the nozzle are presented in Table 4 . The height of corrugation, sheet material, as well as the distance between the individual sheets of the nozzle in the blocks were the same. We changed only the angle $\alpha$ of the inclination of corrugations and, correspondingly, the angle of attack $\beta$.

Using a new geometrical parameter - the angle of nozzle attack $\beta,-$ it was possible to process the experimental results of [36] and to obtain the corresponding plots of the main characteristics of the nozzle, namely the coefficients of hydraulic resistance $\zeta$ and the coefficients $A$ in equation (24).

One can see in Fig. 14 that the dependence of hydraulic resistance $\zeta$ on the angle of attack $\beta$ for all the nozzles is set so as to increase the drag coefficient with increasing the angle $\beta$. When the angle of attack $\beta$ increases from 0 to $90^{\circ}$, the value of the coefficient of hydraulic resistance increases 10 times.

The influence of the layer height $H$ on the nozzle size of the simplex $\frac{\xi}{A}$ at different angles of air flow attack in the range of $\beta$ values within $0-90^{\circ}$ is presented in Fig. 15 . As one can see from the curves in Fig. 15, the highest value of the ratio $\frac{\xi}{A}$ is obtained at the angle of attack $\beta=90^{\circ}$. Then the curves are symbiotically descending to $60^{\circ}, 45^{\circ}, 30^{\circ}$ and $0^{\circ}$.

The effect of attack angle $\beta$ on the value of the coefficient $A$ at the height of the nozzle units $H=2.1$ and $2.8 \mathrm{~m}$ (const) is shown in Fig. 16. One can see that the curves are of the extreme nature with a maximum at values of angles $\beta=40-60^{\circ}$. This reduced height $H$ corresponds to the curve with a large coefficient $A$.
When constructing the graphs in Fig. 16, we used the graphical relationship $A=f(H)$ constructed by us for the angles of attack $\beta=30^{\circ}$ and $\beta=60^{\circ}$ (Fig. 17).

The proposed qualitative hydrodynamic analogy between mixing and plate heat exchangers and the above analysis suggest that the optimal values of the angle of attack $\beta$ in the adjacent heat exchanger plates should range within $40-60^{\circ}$.

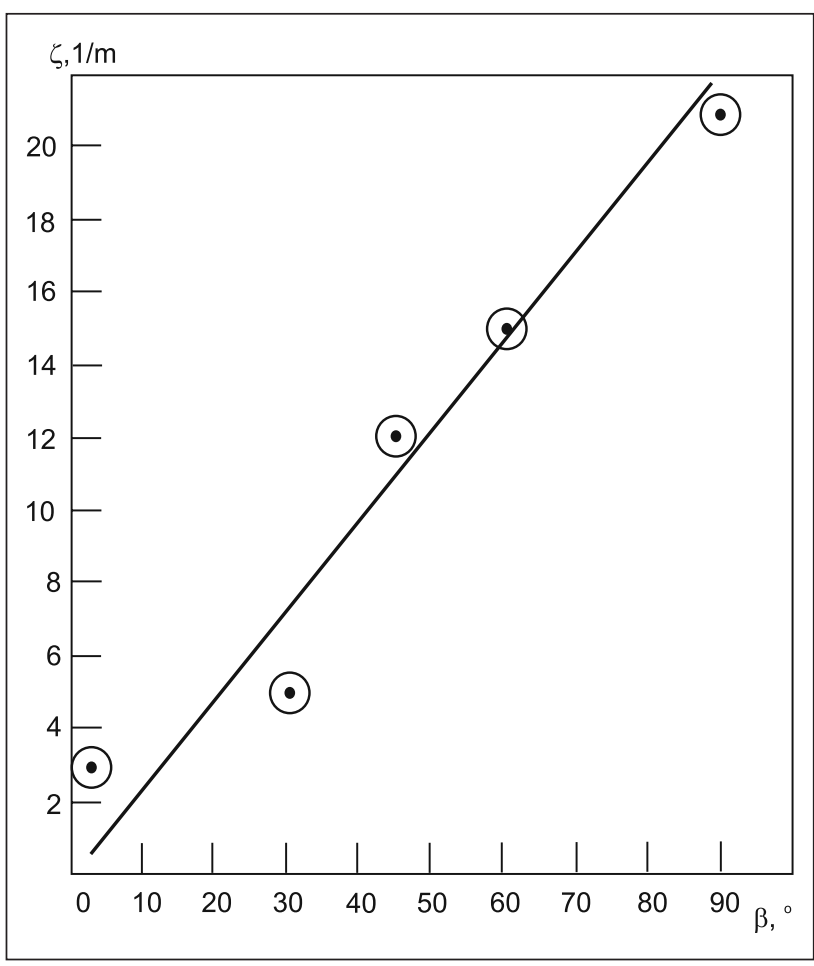

Fig. 14. Dependence of the coefficient of hydraulic resistance of the layer of a regular dry nozzle with oblique corrugations $\zeta$ on the angle of attack $\beta$ at the height of the nozzle layer $H=2.6-2.8 \mathrm{~m}$ 


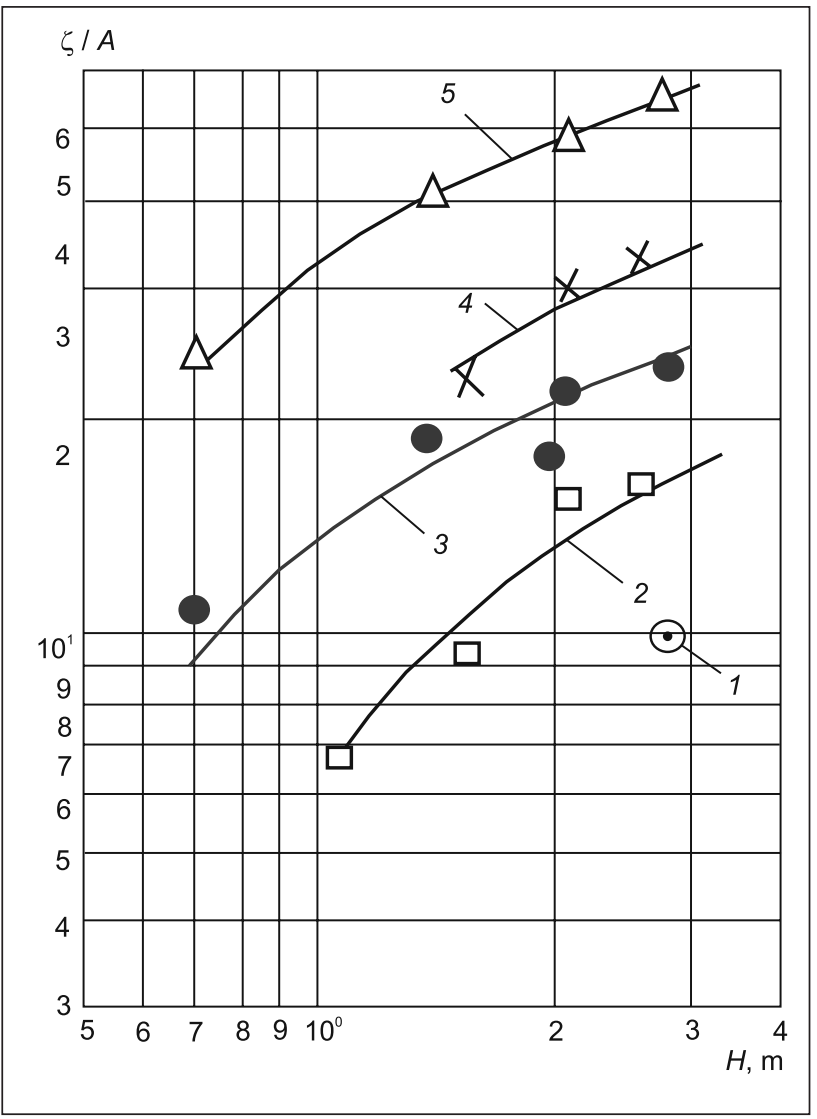

Fig. 15. Dependence of the ratio of the height of the nozzle layer $H$ at angles $\beta$ : $1-0^{\circ}, 2-30^{\circ}, 3-45^{\circ}, 4-60^{\circ}, 5-90^{\circ}$

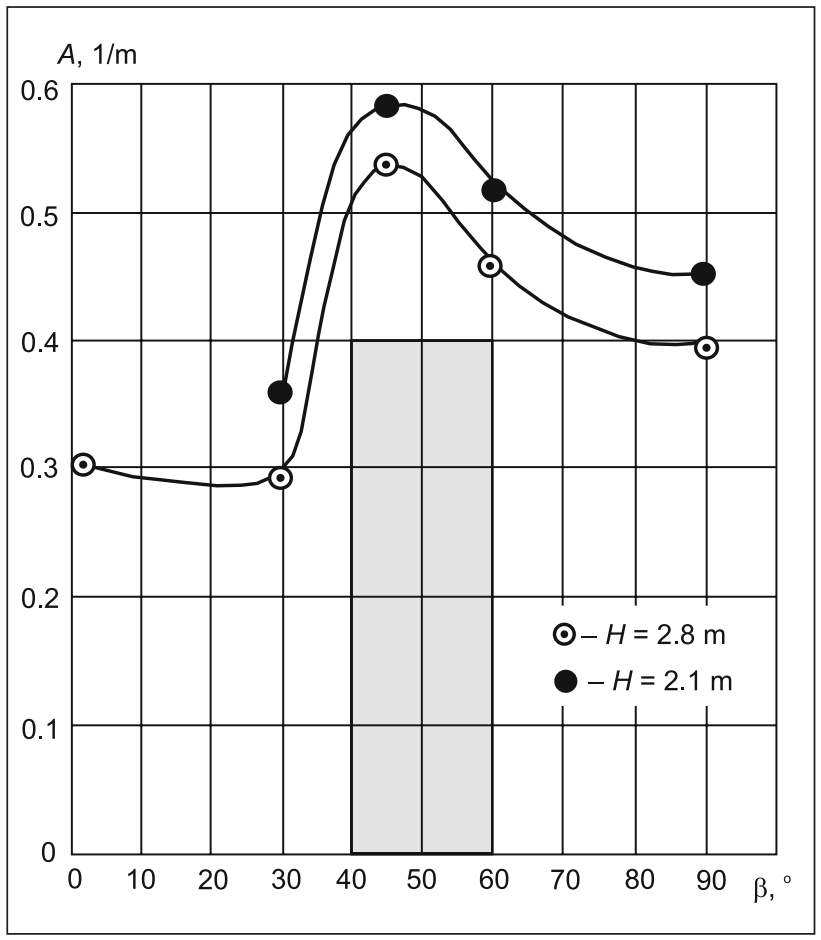

Fig. 16. Dependence of the nozzle on block height $H=2.1 \mathrm{~m}$ and $H=2.8 \mathrm{~m}$ (const). The shaded area shows the maximum value of $A$ corresponding to the range of angles of attack $\beta$ from $40^{\circ}$ to $60^{\circ}$

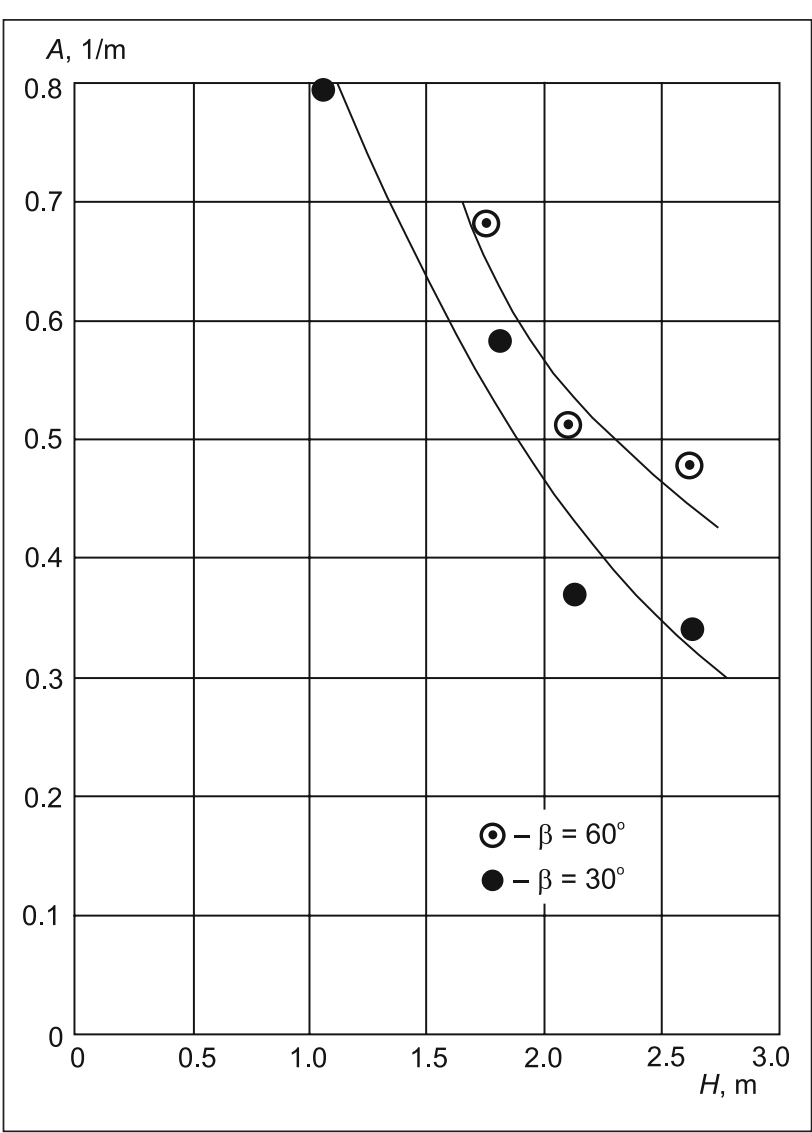

Fig. 17. Dependence for the angle of attack $\beta=30^{\circ}$ and $60^{\circ}$

\section{CONCLUSIONS}

1. Based on the analysis of the flow hydrodynamic stabilization processes at the entrance of channels of various crosssections, we have proposed to limit the length of the channel in the plate heat exchanger zone $Z$, the length of which is determined by the equation $Z=A \cdot\left(\frac{L_{h s t}}{d_{e}}\right)$ where $A=0.33$, $d_{e}$ is the hydraulic radius of the channel, and $L_{h s t}$ is the length of the section of the hydrodynamic stabilization of the flow.

2. A hypothesis of a qualitative hydrodynamic analogy between the current flows in plate heat exchangers and mixing has been advanced. As the geometrical parameter defining the corrugated plates, the angle of attack $\beta$ of the oncoming flow is suggested. On the basis of this hypothesis and the analysis of experimental results concerning the process of evaporative cooling in a regular packing, we found the range of the optimum angle of inclination of the corrugations of adjacent sheets with respect to the design of plate heat exchangers.

Received 29 July 2011

Accepted 31 August 2011 


\section{References}

1. http://www.prombook.ru

2. http://www.mashimpeks.ru

3. http://www.swep.ru

4. http://www.vahterus.com

5. Zhukauskas A. A. Konvektivnyi perenos v teploobmennikakh. Moskva: Nauka, 1982. S. 472.

6. Bogoyavlenskii R. G. Gidrodinamika i teploobmen v vysokotemperaturnykh yadernykh reaktorakh s sharovymi tvelami. Moskva: Atomizdat, 1978. S. 112.

7. Kont-Bello $\mathrm{Zh}$. Turbulentnoye techeniye $v$ kanale s parallelnymi stenkami. Moskva: Mir, 1968. S. 176.

8. Altshul A. D. Gidravlicheskiye soprotivleniya. 2-e izd. pererab. i dop. Moskva: Nedra, 1982. S. 224. Mills K. Dzh. Resheniye nekotorykh problem pri pererabotke nefti s pomoshchyu keramicheskikh tehnologii. Khimicheskaya tekhnika. 2004. No. 10. S. 40-43.

9. Praktikum po teploperedache (pod redakciei A. P. Solodova). Moskva: Energoatomizdat, 1986. S. 252.

10. Liutikas N., Gudzinskas J. Termohidromechanika. Kaunas: Technologija, 2001. $377 \mathrm{~s}$.

11. Kutateladze S. S. Teploperedacha i gidrodinamicheskoye soprotivleniye. Spravochnoye posobiye. M.: Energoatomizdat, 1990. S. 367.

12. Gelperin I. I., Kagan A. M. Razvitiye aerodinamicheskikh issledovanii nepodvizhnogo zernistogo sloya. Khimicheskaya promyshlennost. 1984. No. 12. S. 741-746.

13. Pushnov A., Berengarten M., Shustikov A. Vliyaniye geometrii kanalov reguliarnoi nasadki na gidrodinamiku. Šilumos energetika ir technologijos. Kaunas, 2007 m., vasario 1-2 d. Konferencijos pranešimų medžiaga. Kaunas: Technologija, 2007. P. 203-208.

14. Pushnov A. S., Lozovaya N. P. Vkhodnoi uchastok gidrodinamicheskoi stabilizacii potoka $\mathrm{v}$ reguliarnoi nasadke. Khimicheskaya promyshlennost. T. 86. No. 5. 2009. S. 241-248.

15. Pushnov A. S., Lozovaya N. P., Lagutkin M. G. Model vkhodnogo uchastka gidrodinamicheskoi stabilizatsii potoka $\mathrm{v}$ reguliarnoi nasadke. Khimicheskoe i neftegazovoye mashinostroeniye. 2010. No. 1. S. 4-7.

16. Popov D. N., Panaiotti S. S., Riabinin M. V. Gidromehanika. Pod redakciei D. N. Popova. Izd. vtoroye, stereotipnoye. Moskva: Izdatelstvo MGTU im. N. E. Baumana. 2002. S. 384. (Serija "Mekhanika v technicheskom universitete", t. 6).

17. Tovazhnianskii L. L., Chus M. S., Derevyanchenko I. B., Kapustenko P. A., Yasnogorodskaya T. V. Sozdaniye plastinchatykh teploobmennykh apparatov dlia agregatov sinteza ammiaka. Khimicheskaya promyshlennost. 1986. No. 8. S. $468-471$.

18. Mahnin A. A., Volodin N. I. Ochistka tehnologicheskikh i ventiliacionnykh vybrosov ot organicheskikh rastvoritelei. Khimicheskaya promyshlennost segodnia. 2007. No. 3. S. 41-45.

19. Bulanina E. V., Morozov V. A., Sukhov E. A. Bashennye protivotochnye gradirni vysokoi proizvoditelnosti. Izvestiya VNIIG im. B. E. Vedeneeva. T. 100. Leningrad: Energoatomizdat, 1972. S. 135-144.
20. Spitsyn I. P. Eksperimentalnye gidroaerotermicheskiye issledovaniya plionochnogo orositelya ventiliatornykh gradiren. Trudy koordinacionnykh soveshchanii po gidrotekhnike. Vypusk 115. Problemy tekhnicheskogo vodosnabzheniya moshchnyh TEC i AES. Leningrad: Energiya. 1977. S. 151154.

21. Gelfand R. E., Sverdlin B. L., Shishov V. I. Koefficienty teplo- i massootdachi sovremennych orositelei dlia tehnologicheskikh raschetov gradiren. Elektricheskiye stantsii. 2006. No. 2. S. 24-30.

22. Berman L. D. Isparitelnoye okhlazhdeniye tsirkuliatsionnoi vody. Moskva-Leningrad: Gosenergoizdat, 1953. $309 \mathrm{~s}$.

23. Ponomarenko V. S., Arefyev Yu. I. Gradirni promyshlennykh i energeticheskikh predpriyatii. Spravochnoye posobiye. Pod redakciei Ponomarenko V. S. Moskva: Energoatomizdat, 1998. 372 s.

24. Kolev N., Vinkler K, Darakchiev R., Brosh Z. Sozdaniye effektivnykh nasadok dlia kolonnykh apparatov na osnove teorii massoobmennykh processov. Khimicheskaya promyshlennost. 1986. No. 8. S. 41-45.

25. Sverdlin B. L., Shishov V. I., Pilipenko K. V. Prakticheskiye rekomendatsii po vyboru tehnologicheskogo oborudovaniya pri remonte, stroitelstve i modernizatsii ventiliatornykh gradiren (vybor orositelnykh ustroistv). Himicheskaya tehnika. 2004. No. 1. S. 7-9.

26. Genkin V. S., Lapiga E. Ya. i dr. Patent RF No 2145699 s1, 7F28F25/08. Orositel protivotochnoi gradirni.

27. Dmitrieva G. B., Berengarten M. G., Kliushenkova M. I., Pushnov A. S. Effektivnye konstruktsii strukturirovannykh nasadok dlia protsessov teplomassoobmena. Khimicheskoye i neftegazovoye mashinostroyeniye. 2005. No 8. S. 1517.

28. Linek V., Sinkule J., Brekke K. A critical evaluation of the use of absorption mass transfer data for the design of packed distillation columns. Trans I Chem E. Vol. 73. Part A. May 1995. P. 398-405.

29. Alekseyenko S. V., Markovich D. M., Evseyev A. R. i dr. Eksperimentalnoye issledovaniye raspredeleniya zhidkosti v kolonne so strukturnymi nasadkami. Teoreticheskiye osnovy khimicheskoi tehnologii. 2007. T. 41. No 4. S. 442448.

30. Kagan A. M., Pushnov A. S., Ryabushenko A. S. Sravneniye effektivnosti promyshlennykh nasadok dlia isparitelnogo okhlazhdeniya oborotnoi vody v gradirniakh. Khimicheskaya promyshlennost segodnia. 2007. No 4. S. 44-48.

31. www.zehua-chem.com

32. Kolonny firmy «Zulcer» dlia vakuumnoi rektifikatsii teplochuvstvitelnykh veshchestv. Huber M., Majer V. AO "Gerbiuder Zukker", Shveitsariya.

33. Prospekt firmy „EKO-servis K“, Moskva, 2006.

34. www.2h-kunststoff.de

35. Prospekt kompanii „Koch-Glitsch“, 2003. Publikatsiya KGSP-1 2M0503E.

36. Arefyev Ju. I., Spiridonova N. V. Laboratornye i naturnye issledovaniya orositelei iz polivinilkhlorida. Materialy konferentsiy i soveshchaniy po gidrotekhnike. Gidroaerotermicheskiye issledovaniya $i$ proektirovaniye okhladitelei teplovykh $i$ atomnykh elektrostanciy. VNII im. 
B. E. Vedeneeva, Leningrad: Energoatomizdat, 1985. S. 132-138.

37. Gelfand R. E., Sverdlin B. L., Shishov V. I. Koeffitsienty teplo- i massootdachi sovremennykh orositelei dlia tekhnologicheskikh raschiotov gradiren. Elektricheskiye stancii. 2006. No 2. S. 24-30.

38. Posobiye po proektirovaniyu gradiren ( $\mathrm{k}$ SNiP 2.04.02-84) Moskva: CITP, 1989, $192 \mathrm{s.}$

39. Pushnov A. S., Lagutkin M. G., Petrashova E. N. Novyy sposob reguliarnoi ukladki koltsevykh nasadok dlia osushchestvleniya processov teplo- i massoobmena. Khimicheskaya promyshlennost. 2010. T. 87. No 1. S. 34-36.

40. Kagan A. M., Pushnov A. S. Sravnitelnye kharakteristiki promyshlennykh nasadok dlia processov teplo- i massoobmena. Khimicheskoe i neftegazovoe mashinostroyeniye. 2008. № 4. S. 5-7.

41. Kulov N. N. Gidravlicheskiy raschiot plionochnykh kolonnykh apparatov. Protivotochnye apparaty. Moskva: MIHM, 1979. $33 \mathrm{~s}$.

\section{Aleksandr Pušnov \\ GEOMETRIJOS, TARPUSAVIO IŠDĖSTYMO IR KANALŲ ILGIO İTAKA PLOKŠTELINIŲ ŠILUMOKAIČIŲ EFEKTYVUMUI}

Santrauka

Analizuojami ịvairių plokštelinių šilumokaičių kanalų formos, jų tarpusavio išdėstymo aspektai, susieti su jų hidrodinamika ir šilumos mainų efektyvumu. Tyrimai paremti pasienio sluoksnio teorija, ją taikant pradinio įtekejimo ruožo hidrodinaminei stabilizacijai. Remiantis hidrodinaminès analogijos hipoteze, plokšteliniams ir kitokiems šilumokaičiams, parodyta tarpusavio kanalų išdèstymo ittaka hidrodinamikai ir šilumos mainų procesų efektyvumui.

Raktažodžiai: plokšteliniai ir maišymosi šilumokaičiai, kanalų geometrija, hidrodinamine ịtekejimo stabilizacija, šilumos mainų efektyvumas, aerodinamika, atakos kampas

\section{Александр Пушнов \\ ВЛИЯНИЕ ГЕОМЕТРИИ, ВЗАИМНОГО РАСПОЛО- ЖЕНИЯ И ПРОТЯЖЕННОСТИ КАНАЛОВ ПЛАТИНЧАТЫХ ТЕПЛООБМЕННИКОВ НА ИХ ЭФФЕКТИВНОСТЬ}

Резюме

Анализируются различные аспекты влияния формы, взаимного расположения и протяженности каналов пластинчатых теплообменников на эффективность осуществления процессов гидродинамики и теплообмена. На общих представлениях теории пограничного слоя показана целесообразность учета протяженности входного участка гидродинамической стабилизации потока при создании новых эффективных конструкций пластинчатых теплообменных аппаратов. На основе предлагаемой гипотезы о качественной гидродинамической аналогии между течением потоков в пластинчатом и смесительном теплообменниках показано влияние взаимного расположения каналов соседних пластин на гидродинамику и эффективность процесса теплообмена в пластинчатом теплообменнике.

Ключевые слова: пластинчатые теплообменники, смесительные теплообменники, геометрия каналов, входной участок гидродинамической стабилизации потока, эффективность процессов теплообмена, аэродинамика, удельная поверхность, угол атаки 